Penelitian

\title{
Evaluasi Gambaran Darah dan Marker Stres (Rasio H/L) Ayam Pedaging yang Diberi Daun Bangun-Bangun selama 28 Hari
}

\section{Evaluation of Hematology and Stress Marker (H/L Ratio) of Broilers Administered with Bangun-Bangun Leaves during 28 Days}

\author{
Rindy Fazni Nengsih', Aulia Andi Mustika², Andriyanto² \\ ${ }^{1}$ Mahasiswa Pascasarjana IImu-IImu Faal dan Khasiat Obat (IFO), \\ Fakultas Kedokteran Hewan, Institut Pertanian Bogor \\ ${ }^{2}$ Divisi Farmakologi dan Toksikologi, Departemen Anatomi, Fisiologi, dan Farmakologi, \\ Fakultas Kedokteran Hewan, Institut Pertanian Bogor \\ *Penulis untuk korespondensi: andrifartok@gmail.com \\ Diterima 21 Februari 2020, Disetujui 9 April 2020
}

\begin{abstract}
ABSTRAK
Penelitian ini bertujuan mengetahui pengaruh pemberian simplisia daun bangun-bangun (Coleus amboinicus Lour.) terhadap gambaran darah dan marker stres (rasio H/L) ayam pedaging. Sebanyak 60 ekor ayam pedaging strain Cobb berumur 1 hari (DOC) dibagi ke dalam rancangan acak lengkap yang terdiri atas 4 perlakuan dan 15 ulangan. Ayam percobaan yang diberi tambahan simplisia daun bangun-bangun dalam air minum dengan dosis $0 \%$ (kontrol) dan dosis 0.125 , 0.25 , dan $0.375 \%$ (perlakuan). Pemberian perlakuan dilakukan selama 28 hari secara per oral melalui air minum yang dimulai sejak ayam berumur 8 sampai dengan 35 hari. Analisis darah dilakukan pada masing-masing kelompok perlakuan sebanyak 6 kali. Pengambilan sampel darah dilakukan pada hari ke-7 (sebelum perlakuan) dan 35 (setelah perlakuan). Hasil gambaran darah merah (jumlah butir darah merah, hematokrit, dan hemoglobin) dan diferensial darah putih (monosit, eosinofil, basofil) tidak berbeda nyata ( $p>0.05$ ) pada semua perlakuan baik sebelum dan setelah perlakuan. Setelah perlakuan, ayam yang diberi daun bangun-bangundosis 0.125 dan $0.25 \%$ memiliki rasio $\mathrm{H} / \mathrm{L}$ yang lebih rendah dibanding kontrol $(\mathrm{p}<0.05)$. Hal ini mengindikasikan bahwa pemberian daun bangun-bangun dosis 0.125 dan $0.25 \%$ mampu menurunkan tingkat stres ayam percobaan tanpa disertai perubahan gambaran darah.
\end{abstract}

Kata kunci: ayam pedaging, daun bangun-bangun, hematologi, marker stres, rasio H/L

\begin{abstract}
The research was conducted to investigate the effect of bangun-bangun leaves simplicia (Coleus amboinicus Lour.) on broiler's haematological profile and stress marker ( $\mathrm{H} / \mathrm{L}$ ratio). Sixty day-old chicks strain Cobb broiler chicks were divided into completely randomized design with four treatments and fifteen replications. Experimental broiler were administered bangun-bangun leaves orally in drinking water at a dose of $0 \%$ (control) and dose of $0.125,0.25$, and $0.375 \%$ (treatments). The administration of bangun-bangun leaves was orally for 28 days through drinking water that was started at the age of broiler chicken $8^{\text {st }}$ to $35^{\text {st }}$ days. Blood sampling were collected at $7^{\text {st }}$ day (pre-treatment) and $35^{\text {st }}$ day (post-treatment) at each groups at six times. The research showed that erythrocytes profile (erythrocyte, hemoglobin, hematocrit) and differential of leucocyte (monocyte, eosinophyl, basophyl) all treatments had no significantly $(p>0.05)$ both pre-treatment and post-treatment. Post-treatment (the age of broiler $35^{\text {th }}$ days), the experimental broiler administered bangun-bangun leaves had lower ratio $\mathrm{H} / \mathrm{L}$ as compared to control $(p<0.05)$. It indicated that the administration of bangun-bangun leaves at a dose of 0.125 and $0.25 \%$ decreased stress level of broiler without change of haematological profile.
\end{abstract}

Keywords: broiler, bangun-bangun leaves, haematology, stress marker, $\mathrm{H} / \mathrm{L}$ ratio 


\section{PENDAHULUAN}

Unggas merupakan penghasil protein hewani yang digemari oleh berbagai lapisan masyarakat Indonesia (Rusli et al., 2018). Beternak unggas khususnya ayam pedaging menjadi usaha yang menjanjikan, mengingat dalam waktu yang relatif pendek, ayam pedaging sudah dapat dipanen (Susanto et al., 2019). Umur panen ayam pedaging yang pendek dengan pertumbuhan yang cepat membuat ayam rentan terkena cekaman (stres) dan infeksi penyakit baik yang bersifat menular (contagious) maupun tidak menular (non contagious) (Umar et al., 2017).

Stres pada ayam pedaging dilaporkan oleh Umar et al. (2017) dapat menurunkan pertumbuhan dan kekebalan tubuh sehingga rentan terhadap beberapa penyakit. Penyakit ayam pedaging yang disebabkan oleh penurunan kekebalan tubuhantara lain Infectious Bursal Disease (IBD), Chicken Infectious Anemia (CIA), dan Marek's disease (Hoerr, 2010). Penyakit-penyakit tersebut jika tidak ditanggulangi tentunya menurunkan produktivitas dan meningkatkan mortalitas ayam sehingga menyebabkan kerugian ekonomi (Umar et al., 2017).

Cekaman yang membuat ayam pedaging stres (stresor) dilaporkan dapat berasal dari luar ataupun dalam tubuh ayam (Tamzil, 2014). Stresor yang berasal dari luar tubuh ayam terdiri atas suhu lingkungan, kelembapan, kepadatan flok, dan transportasi (Nangoy, 2012; Tamzil, 2014; Osti et al., 2017), sedangkan stresor dari dalam tubuh ayam antara lain penyakit infeksius dan malnutrisi (Das et al., 2011). Stresor tersebut pada akhirnya akan menimbulkan dampak negatif pada tubuh ternak (Tamzil, 2014).

Alternatifyang sering dilakukan peternak untuk meminimalisir efek stres dan kasus penyakit adalah pemberian multivitamin dan antibiotik sebagai imbuhan pakan. Namun, antibiotiksebagai imbuhan pakan telah dilarang penggunaannya karena bahaya resistensi dan dampak negatif yang ditimbulkan (Mehdi et al., 2018). Solusi alternatif pengganti antibiotik sebagai imbuhan pakan yang saat ini dikembangkan di Indonesia antara lain probiotik, prebiotik, sinbiotik, enzim, acidifier, dan bahan alami atau tanaman herbal (Natalia et al., 2016; Hidayat \& Rahman, 2019).

Salah satu tanaman herbal yang tumbuh di Indonesia dan dilaporkan secara empiris memiliki khasiat meningkatkan kualitas kesehatan manusia adalah tanaman bangun-bangun (Hazimah et al., 2013). Tanaman bangun-bangun (Coleus amboinicus Lour.) merupakan tanaman herbal khas masyarakat
Sumatera Utara yang bagian daunnya diolah menjadi pelengkap hidangan (Syarief et al., 2014). Daun bangun-bangun berdasarkan analisis proksimat menurut Hutajulu \& Junaidi (2013) memiliki kandungan nutrisi yang paling lengkap dibandingkan batang dan ranting. Daun bangunbangun diketahui membantu proses pemulihan ibuibu pasca melahirkan (Hazimah et al., 2013). Daun bangun-bangun juga diketahui mengobati demam malaria, hepatopati, urolithiasis, cistitis, batuk, bronkitis, cacingan, dan epilepsi (Wadikar \& Patki, 2016). Daun bangun-bangun mengandung senyawa bioaktif sebagai antioksidan, antibakteri, dan antifungi (Gurgel et al., 2009; Bhatt \& Negi, 2012; Erny et al., 2014). Berdasarkan uraian yang telah dipaparkan sebelumnya, daun bangun-bangun berpotensi dalam meningkatkan performa dan kesehatan ayam pedaging.

Status kesehatan dan tingkat stres ayam pedaging menurut Muhammed et al. (2015) dan Scanes (2016) dapat diketahui melalui pengamatan profil hematologi dan pengukuran rasio heterofil dan limfosit $(\mathrm{H} / \mathrm{L})$. Parameter hematologi dapat digunakan untuk mengetahui berbagai penyakit yang disebabkan oleh bakteri, parasit, dan respon imunitas tubuh (Hidanah et al., 2018). Selain itu, parameter hematologi dapat mengevaluasi tingkat stres yang diderita oleh ternak (Scanes, 2016).

\section{BAHAN DAN METODE}

\section{Waktu dan Tempat Penelitian}

Pembuatan simplisia daun bangun-bangun di Pusat Studi Biofarmaka Tropika IPB. Penelitian dilakukan di Unit Pengelolaan Hewan Laboratorium, Fakultas Kedokteran Hewan, Institut Pertanian Bogor. Analisis sampel darah di Laboratorium Fisiologi, Departemen Anatomi, Fisiologi, dan Farmakologi, Fakultas Kedokteran Hewan Institut Pertanian Bogor.

\section{Bahan dan Alat}

Penelitian menggunakan hewan percobaan ayam pedaging Day Old Chick (DOC) strain Cobb dengan bobot badan sekitar 35-40 g/ekor sebanyak60 ekor, daun bangun-bangun, pakan komersil, vaksin (Newcastle Disease (ND), Infectious Bursal Disease (IBD), dan booster ND II), dan bahan untuk analisis hematologi. Peralatan yang digunakan adalah timbangan bobot badan, timbangan digital, sentrifus, peralatan kandang pemeliharaan ayam, lemari pendingin, mikroskop cahaya, EDTA vacuum tube, 
termometer, oven, cooling box, kapas, sarung tangan, masker, dan disposable syringe.

\section{Persiapan Bahan, Kandang, dan Hewan Coba}

Penelitian diawali dengan membuat simplisia daun bangun-bangun yang telah dikeringkan menggunakan oven pada suhu $40-45^{\circ} \mathrm{C}$ selama 48 jam. Simplisia dihaluskan menjadi serbuk halus. Serbuk halus daun bangun-bangun ditimbang sesuai dosis pemberian yaitu $0.125,0.25$, dan $0.375 \%$ (\% setara dengan $\mathrm{g} / 100 \mathrm{~mL}$ air minum). Kandang dan peralatan kandang disiapkan seminggu sebelum ayam chick in. Persiapan kandang meliputi pengapuran, desinfeksi, dan penaburan sekam yang ditutup dengan koran.

Hewan percobaan yang digunakan adalah sebanyak 60 ekor ayam pedaging strain Cobb berumur 1 hari (DOC). Sesaat setelah masuk ke kandang, DOC diberi air gula dan multivitamin untuk meminimalisir stres. Selama penelitian, ayam divaksinasi pada hari ke-4, 11, dan 18 berturut-turut dengan vaksin Newcastle Disease (ND), Infectious Bursal Disease (IBD), dan booster ND (ND II). Pakan yang diberikan selama penelitian sesuai dengan standar pakan ayam yang umum digunakan pada peternakan komersial dengan kandungan nutrisi yaitu kadar air $13 \%$, protein kasar $21-23 \%$, lemak kasar $5 \%$, serat kasar $4 \%$, kalsium $0.9-1.10 \%$, dan fosfor 0.6 $0.9 \%$.

\section{Perlakuan dan Pengumpulan Data}

Sebanyak 60 ekor ayam pedaging strain Cobb berumur 1 hari (DOC) dibagi ke dalam rancangan acak lengkap yang terdiri atas 4 perlakuan dan 15 ulangan. Ayam percobaan yang diberi tambahan simplisia daun bangun-bangun dalam air minum dengan dosis $0 \%$ sebagai kontrol dan dosis 0.125 , 0.25 , dan $0.375 \%$ sebagai perlakuan. Perlakuan simplisia daun bangun-bangun mulai diberikan dengan mencampurkan pada air minum pada saat umur ayam 8 sampai 35 hari.

Selama penelitian, pengambilan darah dilakukan sebanyak dua kali, yaitu hari ke-7 (sebelum perlakuan) dan 35 (setelah perlakuan) berturutturut melalui vena jugularis dan axilaris dengan menggunakan disposable syringe $3 \mathrm{~mL}$. Darah kemudian dimasukkan ke dalam tabung EDTA vacuum tube dan dihomogenkan. Preparat ulas dibuat dari sampel darah ayam tersebut. Pengamatan gambaran darah merah dan diferensial darah putih dilakukan dengan pemeriksaan hematologi lengkap atau complete blood count (CBC) dan ulas darah. Pengukuran nilai hematologi dilakukan dengan melihat gambaran darah, yaitu jumlah eritrosit, hemoglobin, nilai hematokrit, leukosit dan diferensiasi leukosit, serta rasio heterofil/limfosit (H/L).

\section{Analisis Data}

Data dianalisis dengan menggunakan analysis of variance (ANOVA) dan dilanjutkan dengan uji Tukey jika hasil yang didapat memperlihatkan adanya pengaruh nyata pada taraf nyata 0.05 .

\section{HASIL}

Pemeriksaan darah merupakan metode yang dapat dilakukan untuk melihat respons fisiologis dan mendukung diagnosis penyakit ternak (Napirah et al., 2013). Pemeriksaan gambaran darah dilakukan untuk mengetahui pengaruh pemberian simplisia daun bangun-bangun (Coleus amboinicus Lour.) terhadap status kesehatan ayam pedaging. Hasil pemeriksaan gambaran darah merah, diferensial darah putih, dan rasio heterofil/limfosit (H/L) ayam pedaging yang diberi simplisia daun bangun-bangun pada umur 7 hari (sebelum perlakuan) disajikan pada Tabel 1.

Hasil uji statistik terhadap hasil hematologi darah ayam pedaging sebelum perlakuan (Tabel 1) menunjukkan bahwa pemberian simplisia daun bangun-bangun dengan dosis $0.125,0.25$, dan $0.375 \%$ melalui air minum tidak memperlihatkan adanya perbedaan nyata ( $p>0.05)$ terhadap kelompok kontrol pada parameter jumlah eritrosit, $\mathrm{Hb}$, dan hematokrit. Hasil pemeriksaan leukosit, diferensial leukosit dan rasio $\mathrm{H} / \mathrm{L}$ pada kelompok kontrol dan perlakuan juga menunjukkan hasil yang tidak berbeda nyata $(p>0.05)$. Hal tersebut menandakan bahwa kondisi ayam pedaging pada semua perlakuan relatif homogen dan tidak mengalami gangguan fisiologis tubuh. Selanjutnya, hasil pemeriksaan gambaran darah merah, diferensial darah putih, dan rasio heterofil/limfosit $(\mathrm{H} / \mathrm{L})$ ayam pedaging yang diberi simplisia daun bangun-bangun pada umur 35 hari (setelah perlakuan) disajikan pada Tabel 2.

Hasil uji statistik terhadap evaluasi gambaran darah ayam pedaging setelah perlakuan (Tabel 2) menunjukkan bahwa pemberian simplisia daun bangun-bangun dengan dosis 0.125, dan 0.25\% melalui air minum memperlihatkan adanya perbedaan nyata $(p<0.05)$ terhadap kelompok kontrol $(0 \%)$ pada 
12 | Nengsih et al.

Tabel 1 Gambaran darah merah, diferensial darah putih, dan rasio heterofil/limfosit (H/L) ayam pedaging yang diberi simplisia daun bangun-bangun pada umur 7 hari (sebelum perlakuan)

\begin{tabular}{|c|c|c|c|c|}
\hline \multirow{2}{*}{ Variabel } & \multicolumn{4}{|c|}{ Daun Bangun-Bangun (\% air minum) } \\
\hline & o (kontrol) & 0.125 & 0.25 & 0.375 \\
\hline $\begin{array}{l}\text { Jumlah eritrosit } \\
\left(10^{6} / \mathrm{mm}^{3}\right)\end{array}$ & $2.97 \pm 0.36^{\mathrm{a}}$ & $2.77 \pm 0.20^{\mathrm{a}}$ & $3.01 \pm 0.28^{\mathrm{a}}$ & $2.62 \pm 0.50^{a}$ \\
\hline Hematokrit(\%) & $24.03 \pm 1.93^{a}$ & $21.63 \pm 3.33^{a}$ & $26.05 \pm 2.06^{\mathrm{a}}$ & $21.79 \pm 4.05^{\mathrm{a}}$ \\
\hline Hemoglobin (g\%) & $9.24 \pm 0.97^{a}$ & $8.21 \pm 0.80^{a}$ & $8.65 \pm 1.32^{\mathrm{a}}$ & $7.95 \pm 1.28^{\mathrm{a}}$ \\
\hline $\begin{array}{l}\text { Jumlah leukosit } \\
\left(10^{3} / \mathrm{mm}^{3}\right)\end{array}$ & $13.82 \pm 4.14^{\mathrm{a}}$ & $8.08 \pm 1.10^{\mathrm{a}}$ & $10.40 \pm 1.54^{\mathrm{a}}$ & $8.95 \pm 1.54^{\mathrm{a}}$ \\
\hline Limfosit (\%) & $56.17 \pm 5.00^{a}$ & $60.83 \pm 4.45^{\mathrm{a}}$ & $63.50 \pm 6.69^{a}$ & $55.00 \pm 10.70^{a}$ \\
\hline Monosit (\%) & $3.17 \pm 0.75^{a}$ & $4.17 \pm 0.75^{a}$ & $3.83 \pm 0.75^{a}$ & $4.33 \pm 1.63^{\mathrm{a}}$ \\
\hline Heterofil (\%) & $39.67 \pm 5.75^{a}$ & $34.00 \pm 3.74^{\mathrm{a}}$ & $32.00 \pm 7.40^{a}$ & $40.67 \pm 9.44^{\mathrm{a}}$ \\
\hline Eosinofil (\%) & $1.00 \pm 0.89^{a}$ & $1.00 \pm 0.63^{a}$ & $0.50 \pm 0.84^{a}$ & $0.00 \pm 0.00^{a}$ \\
\hline Basofil (\%) & $0.00 \pm 0.00^{\mathrm{a}}$ & $0.00 \pm 0.00^{\mathrm{a}}$ & $0.00 \pm 0.00^{a}$ & $0.00 \pm 0.00^{\mathrm{a}}$ \\
\hline$H / L$ & $0.72 \pm 0.16^{\mathrm{a}}$ & $0.57 \pm 0.10^{a}$ & $0.52 \pm 0.18^{\mathrm{a}}$ & $0.80 \pm 0.34^{\mathrm{a}}$ \\
\hline
\end{tabular}

Keterangan: superskrip yang berbeda pada baris yang sama menunjukkan hasil yang berbeda nyata $(\mathrm{p}<0.05)$

Tabel 2 Gambaran darah merah, diferensial darah putih, dan rasio heterofil/limfosit (H/L) ayam pedaging yang diberi simplisia daun bangun-bangun pada umur 35 hari (setelah perlakuan)

\begin{tabular}{lcccc}
\hline \multirow{2}{*}{ Variabel } & \multicolumn{3}{c}{ Daun Bangun-Bangun (\% air minum) } \\
\cline { 2 - 5 } & $0($ Kontrol) & 0,125 & 0.25 & 0.375 \\
\hline Jumlah eritrosit & $3.06 \pm 0.35^{\mathrm{a}}$ & $3.22 \pm 0.25^{\mathrm{a}}$ & $2.90 \pm 0.27^{\mathrm{a}}$ & $3.54 \pm 0.41^{\mathrm{a}}$ \\
$\left(10^{6} / \mathrm{mm}^{3}\right)$ & & & \\
Hematokrit(\%) & $24.244 \pm 3.00^{\mathrm{a}}$ & $26.28 \pm 2.45^{\mathrm{a}}$ & $23.87 \pm 3.60^{\mathrm{a}}$ & $28.63 \pm 4.52^{\mathrm{a}}$ \\
Hemoglobin (g\%) & $15.39 \pm 2.36^{\mathrm{a}}$ & $16.36 \pm 1.15^{\mathrm{a}}$ & $16.17 \pm 1.33^{\mathrm{a}}$ & $16.53 \pm 1.25^{\mathrm{a}}$ \\
Jumlah leukosit & $9.00 \pm 2.93^{\mathrm{a}}$ & $8.32 \pm 1.58^{\mathrm{a}}$ & $10.48 \pm 1.35^{\mathrm{a}}$ & $10.28 \pm 1.32^{\mathrm{a}}$ \\
$\left(10^{3} / \mathrm{mm}^{3}\right)$ & & & \\
Limfosit(\%) & $51.83 \pm 4.26^{\mathrm{b}}$ & $61.00 \pm 4.05^{\mathrm{a}}$ & $63.50 \pm 4.32^{\mathrm{a}}$ & $55.17 \pm 4.75^{\mathrm{ab}}$ \\
Monosit(\%) & $3.42 \pm 1.11^{\mathrm{a}}$ & $4.42 \pm 1.43^{\mathrm{a}}$ & $2.67 \pm 0.82^{\mathrm{a}}$ & $3.50 \pm 1.22^{\mathrm{a}}$ \\
Heterofil $(\%)$ & $44.50 \pm 4.37^{\mathrm{a}}$ & $34.25 \pm 4.02^{\mathrm{b}}$ & $33.58 \pm 4.25^{\mathrm{b}}$ & $40.83 \pm 4.12^{\mathrm{ab}}$ \\
Eosinofil(\%) & $0.17 \pm 0.41^{\mathrm{a}}$ & $0.17 \pm 0.41^{\mathrm{a}}$ & $0.17 \pm 0.41^{\mathrm{a}}$ & $0.58 \pm 0.80^{\mathrm{a}}$ \\
Basofil (\%) & $0.00 \pm 0.00^{\mathrm{a}}$ & $0.00 \pm 0.00^{\mathrm{a}}$ & $0.00 \pm 0.00^{\mathrm{a}}$ & $0.00 \pm 0.00^{\mathrm{a}}$ \\
H/L & $0.87 \pm 0.17^{\mathrm{a}}$ & $0.57 \pm 0.10^{\mathrm{b}}$ & $0.54 \pm 0.10^{\mathrm{b}}$ & $0.74 \pm 0.13^{\mathrm{ab}}$ \\
\hline
\end{tabular}

Keterangan: superskrip yang berbeda pada baris yang sama menunjukkan hasil yang berbeda nyata $(\mathrm{p}<0.05)$

parameter persentase limfosit, heterofil, dan rasio $\mathrm{H} / \mathrm{L}$ dibandingkan kelompok kontrol dan simplisia daun bangun-bangun dosis $0.375 \%$. Pemberian simplisia daun bangun-bangun dosis 0.125 dan $0.25 \%$ mampu menurunkan rasio $\mathrm{H} / \mathrm{L}$ dibandingkan kelompok kontrol dan simplisia daun bangunbangun dosis $0.375 \%$. Sementara itu, nilai dari parameter jumlah leukosit pada kelompok perlakuan dan kontrol tidak terlihat adanya perbedaan nyata. Monosit, eosinofil, dan basofil pada kelompok kontrol dan perlakuan juga tidak menunjukkan perbedaan nyata dan masih memenuhi nilai normal menurut Samour (2013) yaitu berturut-turut-turut $0.0-1.0 \%, 0.5-7.6 \%$, dan $0.0-1.0 \%$.

Hasil parameter eritrosit, $\mathrm{Hb}$, dan hematokrit pada kelompok kontrol dan simplisia daun bangun-bangun setelah perlakuan masih berada dalam rentang normal (Tabel 2). Laporan Samour (2013) menyatakan bahwa rentang normal jumlah eritrosit pada ayam berkisar $2.5-3.9 \times 10^{6} / \mathrm{mm}^{3}$. Nilai hematokrit dan hemoglobin pada kisaran normal menurut Samour (2013), yaitu 30-49\%, dan 10.2-15.19\%. 


\section{PEMBAHASAN}

Pemberian simplisia daun bangun-bangun dosis bertingkat (0.125, 0.25, dan $0.375 \%$ ) melalui air minum pada ayam pedaging setelah perlakuan tidak mengalami perbedaan nyata terhadap nilai hematokrit, kadar hemoglobin, dan jumlah eritrosit. Nilai hematokrit, kadar hemoglobin, dan jumlah eritrosit yang normal pada setiap perlakuan menunjukkan bahwa protein dan asam amino dalam ayam tercukupi untuk proses metabolisme tubuh ayam pedaging (Piliang et al., 2009). Hal tersebut menandakan bahwa fungsi komponen darah berjalan dengan baik dalam mengantarkan nutrisi dan oksigen sehingga dapat meningkatkan performa ayam pedaging. Hal tersebut juga menunjukkan bahwa pemberian daun bangunbangun tidak memengaruhi fisiologis tubuh ayam.

Perubahan parameter darah ayam pedaging setelah perlakuan terukur signifikan menurunkan rasio $\mathrm{H} / \mathrm{L}$ ayam pada kelompok perlakuan simplisia bangun-bangun dosis 0.125 dan $0.25 \%$ dibanding kontrol dan dosis tertinggi $0.375 \%$. Heterofil merupakan jenis granulosit dari leukosit yang berperan sebagai pertahanan leukosit pertama yang muncul saat peradangan dan infeksi akut. Limfosit yang merupakan jenis agranulosit dari leukosit memiliki peranan sebagai sel pertahanan lanjutan yang berperan dalam melisiskan sel toksik (limfosit T) dan membentuk kekebalan tubuh (limfosit B). Rasio $\mathrm{H} / \mathrm{L}$ dapat disebut sebagai indikator stres pada ayam (Scanes, 2016). Kondisi stres merupakan kondisi kritis pada ayam pedaging karena akan memengaruhi produktivitas ayam.

Penurunan feed intake dapat terjadi akibat stres. Penurunan feed intake menyebabkan tubuh memecah karbohidrat, protein, dan lemak yang ada di dalam tubuh sebagai kompensasi terhadap kebutuhan glukosa pada sel dan jaringan. Perombakan karbohidrat, protein, dan lemak melalui jalur siklus krebs, oksidasi asam amino, dan $\beta$ oksidasi menghasilkan radikal bebas. Radikal bebas tidak hanya berasal dari proses metabolisme, tetapi juga dari proses fagositosis (Nawab et al., 2018). Proses fagositosis akan menghasilkan radikal bebas. Radikal-radikal bebas tersebut dapat menyebabkan terjadinya stres oksidatif. Stres juga dapat merangsang pengeluaran hormon kortikosteron yang akan menekan aktivitas limfosit sehingga menurunkan jumlah limfosit dalam darah ayam (Scanes, 2016).

Simplisia daun bangun-bangun berdasarkan uji fitokimia memiliki kandungan flavonoid, tanin, saponin, dan steroid. Laporan Silitonga et al. (2015) menyatakan bahwa komponen flavonoid yang dimiliki daun bangun-bangun adalah quercetin, apigenin, luteolin, salvigenin, dan genkwanin. Senyawa-senyawa tersebut berperan sebagai antioksidan. Antioksidan merupakan suatu senyawa yang dapat menghambat, mencegah, atau mengurangi hasil dari proses oksidasi radikal bebas. Laporan Arumugam et al. (2016) menyatakan bahwa ekstrak air dari daun bangun-bangun memiliki aktivitas antioksidan yang tinggi terhadap radikal bebas superoksida $\left(\mathrm{O}_{2}^{-}\right)$, nitrit oksida ( $\left.\mathrm{NO}^{-}\right)$dan kelasi ion Fe. Aktivitas antioksidan tersebut membantu meminimalisir terjadi stres oksidatif akibat kondisi stres.

Pemberian simplisia daun bangun-bangun 0.125 dan $0.25 \%$ melalui air minum mampu menurunkan rasio $\mathrm{H} / \mathrm{L}$ yang merupakan salah satu marker stres pada ayam pedaging $(\mathrm{p}<0.05)$. Pemberian simplisia daun bangun-bangun dosis $0.125,0.25$, dan $0.375 \%$ tidak memengaruhi perubahan gambaran darah sehingga dapat dikatakan tidak menyebabkan gangguan fisiologis pada ayam pedaging.

"Penulis menyatakan tidak ada konflik kepentingan dengan pihak-pihak yang terkait dalam penelitian ini".

\section{DAFTAR PUSTAKA}

Arumugam G, Swamy MK, Sinniah UR. 2016. Review: Plectranthus amboinicus (Lour.) Spreng: botanical, phytochemical, pharmacological and nutritional significance. Molecules 21:1-26. doi: 10.3390/molecules21040369.

Bhatt P, Negi PS. 2012. Antioxidant and antibacterial activities in the leaf extracts of Indian borage (Plectranthus ambionicus). Food and Nutrition Sciences 3:146-152. doi: 10.4236/fns.2012.32022.

Das S, Palai TK, Mishra SR, Das D, Jena B. 2011. Nutrition in relation to diseases and heat stress in poultry. Veterinary World 4(9):429-432. doi: 10.5455/vetworld.2011.429-432.

Erny SMN, Razali M, Mirfat AHS, Mohd Sukri MA. 2014. Antimicrobial activity and bioactive evaluation of Plectranthus amboinicus essential oil. American Journal of Research Communication 2(12): 121-127. https://www. researchgate.net/ publication/ 312557731_Antimicrobial_activity_ and_bioactive_evaluation_of_Plectranthus_amb oinicus_essential_oil 
Gurgel APAD, Da Silva JG, Grangeiro ARS, Xavier HS, Oliveira RAG, Pereira MSV, De Souza IA. 2009. Antibacterial effects of Plectranthus amboinicus (Lour.) Spreng (Lamiaceae) in Methicillin Resistant Staphylococcus aureus (MRSA). Latin American Journal of Pharmacy 28(3):460-464. https://www.researchgate.net/publication/ 238116877_Antibacterial_Effects_of_Plectranthus _amboinicus_Lour_Spreng_Lamiaceae_in_Methi cillin_Resistant_Staphylococcus_aureus_MRSA.

Hazimah, Teruna HY, Jose C. 2013. Aktivitas antioksidan dan antimikrobial dari ekstrak Plectranthus amboinicus. Jurnal Penelitian Farmasi Indonesia 1(2):39-42. https://pfi.ejournal.unri.ac. id/index.php/FPFI.

Hidanah S, Sabdoningrum EK, Wahjuni RS, Chusniati S. 2018. Effects of meniran (Phyllanthus niruri L.) administration on leukocyte profile of broiler chickens infected with Mycoplasma gallisepticum. Veterinary World 11(6):834-839. doi: 10.14202/ vetworld.2018.834-839.

Hidayat C, Rahman. 2019. Review: peluang pengembangan imbuhan pakan fitogenik sebagai pengganti antibiotika dalam ransum ayam pedaging di Indonesia. Jurnal Ilmu dan Teknologi Peternakan Tropis 6(2):188-213. http://ojs.uho.ac.id/ index. php/peternakan-tropis/article/view/7139.

Hoerr FJ. 2010. Clinical aspects of immunosuppresion in poultry. Avian Disease 54:2-15. doi: 10.1637/8909-043009-Review.1.

Hutajulu TF, Junaidi L. 2013. Manfaat ekstrak daun bangun-bangun (Coleus amboinicus L.) untuk meningkatkan produksi air susu induk tikus. Jurnal Riset Industri 7(1):15-24. http://ejournal. kemenperin.go.id/jri/article/view/3235.

Mehdi $Y$, Letourneau-Montminy $M$, Gaucher $M$, Chorfi Y, Suresh G, Rouissi T, Brar SK, Cote C, Ramirez AA, Godbout S. 2018. Use of antibiotics in broiler production: global impacts and alternatives. Animal Nutrition 4:170-178. doi: 10.1016/j.aninu.2018.03.002.

Muhammed Al, Adamu SB, Alade NK, Amin AB, Abdulazeez H. 2015. Studies on haematology and serum biochemistry of broiler chickens finished on an unprocessed and processed velvet bean (Mucuna pruriens L.) as dietary protein source. Biokemistri 27(2):68-75. https://www.ajol.info/ inin-

dex.php/biokem/article/viewFile/133060/122686.

Nangoy FJ. 2012. Kajian penyusutan berat badan dan peningkatan suhu tubuh ayam pedaging terimplementasi kurkuma (curcuma longa), gula aren (arenga pinata) akibat lama transportasi.
International Journal of Agriculture System 2(3):119-122. doi: 10.24198/ijas.v2i3.2745.

Napirah A, Supadmo, Zuprizal. 2013. Pengaruh penambahan tepung kunyit (Curcuma domestica Valet) dalam pakan terhadap parameter hematologi darah puyuh (Coturnix-coturnix japonica) pedaging. Buletin Peternakan 37(2):114119. doi: 10.21059/buletinpeternak.v37i2.2429.

Natalia D, Suprijatna E, Muryani R. 2016. Pengaruh penggunaan limbah industri jamu dan bakteri asam laktat (Lactobacillus sp.) sebagai sinbiotik untuk aditif pakan terhadap performans ayam petelur periode layer. Jurnal Imu-Ilmu Peternakan 26(3):6-13 doi: 10.21776/ub.jiip.2016.026.03.02.

Nawab A, Ibtisham F, Li G, Kieser B, Wu J, Liu W, Zhao Y, Nawab Y, Li K, Xio M, An L. 2018. Heat stress in poultry production; Mitigation strategies to overcome the future challenges facing the global poultry industry. Journal of Thermal Biology 78:131-139. doi: 10.1016/j.jtherbio. 2018.08.010.

Osti R, Bhattarai D, Zhou D. 2017. Climatic variation: effects on stress levels, feed intake, and bodyweight of broilers. Brazilian Journal of Poultry Science 19(3):489-496. doi: 10.1590/18069061-2017-0494.

Piliang WG, Astuti DA, Hermana W. 2009. Pengkayaan produk puyuh melalui pemanfaatan pakan lokal yang mengandung antioksidan dan mineral sebagai alternatif penyediaan protein hewani bergizi tinggi. Prosiding seminar hasilhasil penelitian IPB Bogor. Bogor. p27-39.

Rusli, Novieta ID, Rasbawati. 2018. Kandungan protein dan kadar air bakso daging ayam pedaging pada penambahan bahan pengenyal yang berbeda. Bionature 19(2):126-133. doi: 10.35580/bionature.v19i2.9730.

Samour J. 2013. Diagnostic value of hematology. In: Harrison G, Lightfoot T; editors. Clinical Avian Medicine. Florida (US): Spix Publisher.

Scanes CG. 2016. Biology of stress in poultry with emphasis on glucocorticoids and the heterophil to lymphocyte ratio. Poultry Science 95(9):22082215. doi: 10.3382/ps/pew137.

Silitonga M, Ilyas S, Hutahaean S, Sipahutar H. 2015. Levels of apigenin and immunostimulatory activity of leaf extracts of bangun-bangun (Plectranthus amboinicus Lour). International Journal of Biology 7(1):46-53. doi: 10.5539/ijb. v7n1p46.

Susanto H, Herawati M, Rastosari A. 2019. Pengaruh perlakuan sexing terhadap konsumsi pakan, 
pertambahan berat badan, dan konversi pakan ayam ras pedaging dikandang semi closed house. Wahana Peternakan 3(1):26-33. doi: 10.37090/ jwputb.v3i1.114.

Syarief H, Damanik RM, Sinaga T, Doloksaribu TH. 2014. Pemanfaatan aun bangun-bangun dalam pengembangan produk makanan tambahan fungsional untuk ibu menyusui. Jurnal IImu Pertanian Indonesia 19(1):38-42. https://journal. ipb.ac.id/index.php/ JIPI/article/view/8404.

Tamzil MH. 2014. Stres panas pada unggas: metabolisme, akibat, dan upaya penanggulangannya.
Wartazoa 24(2):57-66. http://medpub.litbang. pertanian.go.id/ index.php/wartazoa/article/ download/1049/1058.

Umar S, Munir MT, Ahsan U, Raza I, Chowdhury MR, Ahmed Z, Shah MAA. 2017. Immunosuppressive interactions of viral diseases in poultry. World's Poultry Science Association 73:121-135. doi: 10.1017/ So043933916000829.

Wadikar DD, Patki PE. 2016. Coleus aromaticus: a therapeutic herb with multiple potentials. Journal of Food Science and Technology 53(7): 2895-2901. https://www.ncbi.nlm.nih.gov/ pmc/ articles/PMC5052183/. 